\title{
An Analysis of Taboo Words in Rich Brian's Song Lyrics
}

\author{
Derli Elsa Putri \\ English Education Study Program, Department of Language and Art \\ University of Bengkulu \\ derlielsa97@gmail.com \\ Barnabas Sembiring \\ English Education Study Program, Department of Language and Art \\ University of Bengkulu \\ barnabasdepari@gmail.com \\ Imranuddin \\ English Education Study Program, Department of Language and Art \\ University of Bengkulu \\ imranulama@gmail.com
}

\begin{abstract}
This research aimed at investigating taboo words in Rich Brian's song lyrics. The researcher described what kinds, functions, and meanings of taboo words used in Rich Brian's song lyrics. The sample of this research was five Rich Brian's song lyrics that collected by using simple random sampling. The researcher employed a theory from Batistella to describe the kinds of taboo words and a theory from Wardhaugh to describe the functions of taboo words. Then, in finding the meaning of taboo words in Rich Brian's song lyrics the researcher employed some dictionaries, internet and article as well to support the data. In addition, this research was completed assisted by co-researcher. The result showed that there were 89 taboo words found in those five song lyrics where obscenity was the highest kind of taboo words which mentioned 49 times $(45 \%)$ and profanity was the least which mentioned 6 times (7\%). Then, in functions of taboo words showing contempt became the commonly used while mocking authority became the least used. Furthermore, according to the sociolinguistic point of view this kind of music surely is not Indonesian culture but it is more to western culture where many rapper come from there and it usually spoken by specific class of people.
\end{abstract}

Keyword: Taboo words, Rich Brian, Song Lyrics

\begin{abstract}
ABSTRAK
Penelitian ini bertujuan untuk meneliti kata-kata tabu di lirik lagu Rich Brian. Peneliti menjelaskan jenis, fungsi, dan arti dari kata-kata tabu yang ada di lirik lagu Rich Brian. Sampel dari penelitian ini adalah lima lagu dari Rich Brian yang diambil dengan menggunakan penarikan contoh acak sederhana. Peneliti menggunakan teori dari Batistella untuk mendeskripsikan jenis-jenis dari kata tabu dan teori dari Wardhaugh untu
\end{abstract}


mendeskripsikan fungsi-fungsi dari kata tabu. Kemudian, dalam menemukan arti dari kata tabu di lirik lagu Rich Brianpeneliti menggunakan beberapa kamus, internet dan artikel juga untuk mendukung data. Sebagai tambahan, penelitian ini dibantu oleh pendamping peneliti. Hasil dari penelitian ini menunjukkan bahwa ada 89 kata-kata tabu yang ada di kelima lagu tersebut dimana obscenity adalah jenis kata tabu tertinggi yang disebutkan sebanyak 49 kali (45\% dan profanity adalah jenis kata tabu terendah yang disebutkan 6 kali (7\%). Kemudian, untuk fungsi kata-kata tabu showing contempt menjadi yang paling banyak yang digunakan sedangakan mocking authority menjadi yang paling sedikit digunakan. Selanjutnya, menurut sudut pandang sosiolinguistik jenis musik ini tentunya bukan budaya Indonesia tetapi lebih merupakan budaya barat dimana banyak penyanyi rap berasal dari sana dan biasanya ini diucapkan oleh orang tertentu.

Kata Kunci: Kata-kata tabu, Rich brian, Lirik Lagu

Kata Kunci: Kata-kata tabu, Rich Brian, Lirik Lagu

\section{INTRODUCTION}

Language is a symbol of sound system which takes a role as an important aspect in human life as a means of communication to convey idea, message, intention, and opinion to other people, without language people will not be able to communicate each other.

The study of language is called Linguistic. According to Martinet (1987) linguistic is the study which takes language as an object, how it is put together and how it functions. There are various branches of linguistics, one of them is Sociolinguistic. Sociolinguistic is the study that talks about the correlation between society and language, it is about the use of language by individuals in its social context.

As we know that when we talk about language, it relates with the society, just like what have been said by Hickerson (1980) sociolinguistic is the developing subfield of linguistic which takes speech variation as its social context and Hudson (1980) said that sociolinguistic is the study of language in relation to society. In sociolinguistic we study language and society in order to find out as much as we can about what kind of thing language is. There are many parts of sociolinguistic subjects one of them is Taboo words.

Taboo is a cultural custom that does not allow people to do, use or talk about a particular thing as people find it as word which is offensive 
and embarrassing, and it also refers to the words that many people consider because they refer to sex, body or people's race. Wardhaugh (2000) said that taboo is prohibition or avoidance that cannot be used by human being in any society because it will hurt its members and make them feel anxious, embarrassment, or shame.

Taboo words are always considered as inappropriate words to utter in daily conversation, because these taboo words are associated to harsh meaning. For Indonesian people taboo words are the same as reproach. Therefore the use of taboo words is greatly avoided to be said, people who say taboo words are considered as people who are impolite and put aside the norms of polite behaviour and ethic applied in Indonesia.

However, there are still argumentations in defining the taboo words by human being. Some people think and believe that taboo is something that has negative meaning, and emotion to express the negative types of feeling towards the others, especially when it used in public areas or to someone who older than us. On the other hand, nowadays the attitude towards the function of taboo words has already changed. Based on Anggita (2015), she said that the changes happened because of the legal sanctions were getting more relaxed to accept taboo words.

As a result, taboo words are now commonly found when someone expresses the emotive feeling. Some people believe that by using taboo words is one of the ways that can be used to convey or to express their feeling and emotion. Sometimes it mostly happen when someone in emotional condition because that word unintentionally spoken and they cannot control the words or when someone speak and communicate with their close friend in order to express that they closely enough as a friend. For example the words like: bastard, shit, bitch, and fuck.

Many taboo words have been used in song especially in RAP songs. Rap is a music genre that is spoken quickly than actual, songs usually with an electronic rhythm accompaniment. This kind of music is widely used and favoured by many people especially young people. One of the reasons why young people love this rap music is because Rap music is a lifestyle and covers all classes of young people and also many rapper use 
expressive and straightforward lyrics which are certainly suitable for those who are young and enthusiastic. So that is why many young people love this kind of music.

Rich Brian is one of famous rap singer. He is a rapper from Indonesia who recently got famous because of his single entitled Dat \$tick which was first released in February 2016. Even though Rich Brian often puts taboo words his song lyrics in order to express his ideas, thoughts, and feeling but many people still like it. This is due to the fact that Rich Brian has his own characteristic which is bass-voice sound, excellence music and Iyrics, fun drill-rap with catchy hook, and perfect English-American Pronunciation. Furthermore, Rich Brian became an inspiration for young people today because of his success at a young age.

Example of his song contained taboo words is "Dat \$tick" which released in 2016

People be starvin'

And people be killin' for food with that crack and that spoon

But these rich mothafuckas, they stay eatin' good

Droppin' wage livin' good. Holdin' steel Glocks, but you been a bitch, suck a thick cock

Fuck a Crip walk, hit the strip like in Bangkok

Never ever see me have a trip 'bout a lil' broad See me on the TV screamin', "Bitch, you a damn fraud"

Therefore, according to the explanation above, the researcher intends to identify and analyse kinds and functions of taboo words along with their meanings in Rich Brian's song lyrics.

\section{METHOD}

This research employed a descriptive qualitative research. Descriptive qualitative is method where the data will be described in form of words, clauses, phrases, and sentences. According to Crabtree and Miller (1999) Qualitative descriptive explores the meaning, variation, perceptual experience of phenomena and capture the overall nature or 
interrelated. Besides, this researcher was also done along with the help of co-researcher in analysing the data.

POPULATION

In this study, the population that will be selected by the researcher is all of Rich Brian's song lyrics which consist of 24 songs.

Sample

Sample is a part of the population which taken by according to certain procedures that can be used to represent the population. Because this research was classified as qualitative research, research sampling process was done by using random sampling technique. Sugiyono (2010) defined the simple random sampling is taking the sample randomly. It means that all member of population has equal chance to be the sample.

In addition, according to Gay \& Diehl (1992), generally the number of respondents acceptable for a study depends upon the type of research involved - descriptive, correlational or experimental. For descriptive research the sample should be $10 \%$ of population. But if population is small then $20 \%$ may be required. By using random sampling, 5 song lyrics or $20 \%$ of song lyrics were selected. The list of sample song lyrics will be attached in Appendix 2.

INSTRUMENTS

In qualitative research, the researcher acts as the main instrument. (Moleong: 2009). It means, the researcher should plan, collect, analyse, and describe or report the data. Moreover, observation checklist was also used as the secondary instrument. The observation checklist was functioned to write down the classified data. The observation checklist was in the form of a table for presenting four objectives which became the focus of the study, which are the kinds and functions of taboo words along with their meanings.

\section{RESULTS}

The result showed that there were 89 taboo words found in Rich Brian's song lyrics. Obscenity ( $\left.f^{* * * *} n g, f^{* *} k, s^{* *}\right)$ dominated the appearance. The 
second most frequently appearing kind of taboo word was epithet $\left(m^{* * * * * * * *}\right.$ ker, $n^{* *} g a$, and $\left.p^{*} g, b^{* * *} h\right)$, the third was vulgarity (a**, p*ssy, $\left.d^{*} c k n^{*} n i\right)$ and the last was profanity (j*sus C*rist, $g^{*} d d a m n, d^{*} m n$ ).

Table 1: Kinds of Taboo Words in 5 Rich Brian's song lyrics in General

\begin{tabular}{|c|c|c|c|}
\hline \multirow{2}{*}{ No } & \multirow{2}{*}{ Kinds of Taboo Words } & \multicolumn{2}{|c|}{ Total } \\
\hline & & Researcher & Co-researcher \\
\hline 1 & Obscenity & 40 & 40 \\
\hline 2 & Epithet & 31 & 31 \\
\hline 3 & Vulgarity & 12 & 12 \\
\hline 4 & Profanity & 6 & 6 \\
\hline \multicolumn{2}{|c|}{ Total } & 89 & 89 \\
\hline
\end{tabular}

Diagram 1: Percentage Kinds of Taboo Words of 5 Rich Brian's song lyrics in General (\%)

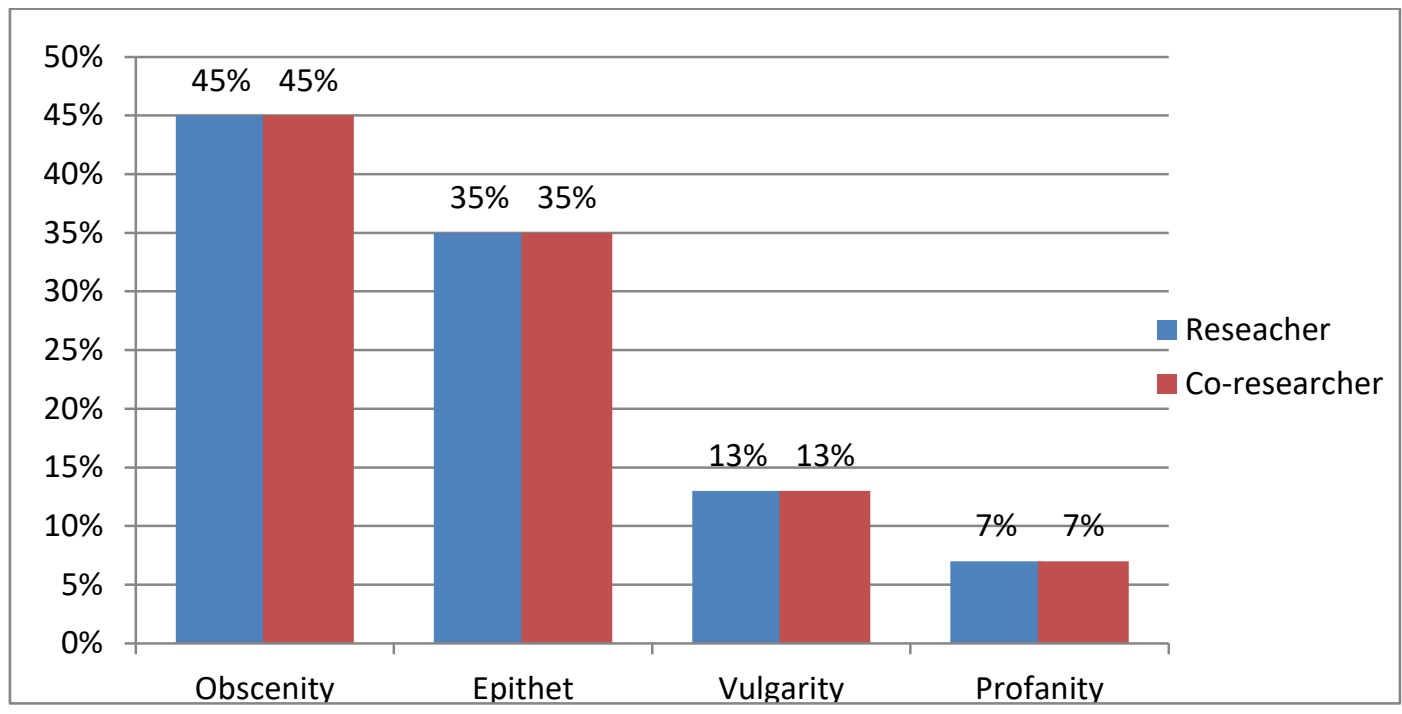

Based on the table and diagram above, there were four kinds of taboo words, i.e. Obscenity, epithet, vulgarity and profanity. All of them appeared in Rich Brian's song lyrics (Back at it, Crisis, Dat \$tick, Seventeen and Who that be). Both researcher and co-researcher got the same result in analysing the kinds of taboo words.

It can be noticed that the highest kind of those five song lyrics is obscenity which appeared 40 times $(45 \%)$, the second is epithet which 
appeared 31 times (35\%), the third is Vulgarity which appeared 12 times (13\%) and the lowest is profanity which appeared only 6 times (7\%).

According to Ronal Wardhaugh 's theory the functions of taboo words appeared in this research namely drawing attention to oneself, showing contempt, being provocative and mocking authority. The general result finding is shown in the following table and diagram.

Table: Functions of Taboo Words in 5 Rich Brian's song lyrics in General

\begin{tabular}{|c|c|c|c|}
\hline \multirow{2}{*}{ No } & \multirow{2}{*}{ Kinds of Taboo Words } & \multicolumn{2}{|c|}{ Total } \\
\cline { 3 - 4 } & & Researcher & Co-researcher \\
\hline 1 & Showing Contempt & 49 & 49 \\
\hline 2 & Drawing Attention & 29 & 30 \\
\hline 3 & Being Provocative & 9 & 8 \\
\hline 4 & Mocking Authority & 2 & 2 \\
\hline \multicolumn{2}{|c|}{ Total } & 89 & 89 \\
\hline
\end{tabular}

Diagram 7: Percentage Functions of Taboo Words of 5 Rich Brian's song lyrics in General (\%)

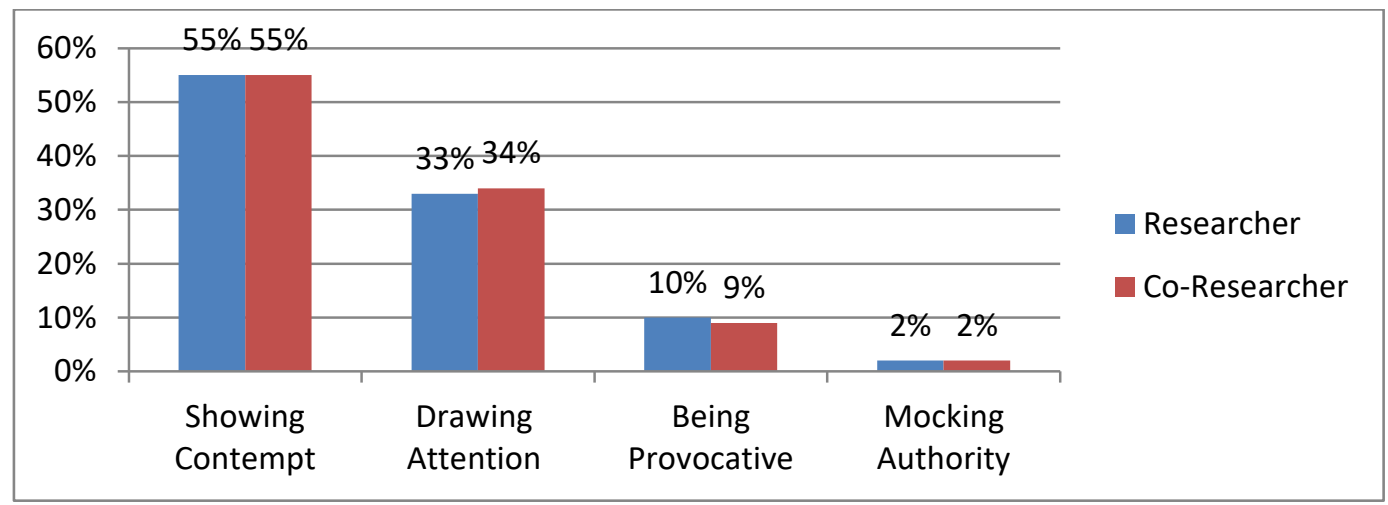

Based on the table and diagram above it can be seen that the highest frequency for functions of taboo words in 5 song lyrics of Rich Brian was showing contempt, second was drawing attention, third was being provocative and the least was mocking authority. Then, we also can clearly see that both researcher and co-researcher got different result when analysing the data which occur in the result of drawing attention and showing contempt. 


\section{DISCUSSIONS}

After analysing the data the researcher found that there were many taboo words have been found in 5 song lyrics of Rich Brian with the total number of 89 taboo words. Despite of hailing from Jakarta, Indonesia where people who speak taboo words considered as people who are impolite and put aside the norms of polite behaviourur and ethics applied in Indonesia, Rich Brian always puts taboo words in each of his songs. This is due to the facts that he has been influenced by west culture where he live right now and those songs that contained taboo words written by Brian was used to represent his emotive feeling towards the others.

Then, the researcher found that obscenity was the highest kind of taboo words used in 5 song lyrics of Rich Brian. While profanity became the least kind of taboo words used in this research. Obscenity became the highest kind because Rich Brian used a lot taboo words like shit and fuck in his song lyrics which is categorized as obscenity. And profanity became the least used kind of taboo words, it was because the religious cursing like damn and goddamn were not widely used in Rich Brian's songs.

In functions of taboo words the most commonly used was showing contempt and mocking authority became the least. In his song lyrics Rich Brian mostly used taboo words in order to show contempt by insulting the addresse, situation, or environment because those were worthless and cannot be respected.

Afterwards, there were many taboo words in 5 songs of Rich Brian that have different meaning because of different context. For instance the word shit is related to excretory term; however, indeed the meaning will be different based on the context where it used. It can be translated as nonsense when it was added with the word "talking" became talking shit "means talking nonsense"

\section{CONCLUSIONS AND SUGGESTIONS}

CONCLUSIONS

Based on results and discussions, there are some conclusions. Firstly, Rich Brian used many taboo words in each of his song lyrics. Those taboo 
words are used by Rich Brian in order to express his emotions and feelings towards the others. Even though Brian is Indonesians teenager but he always put taboo words in his song lyrics because he is a rapper and he has been affected by west culture. That is why there are so many taboo words in Rich Bran's song lyrics.

Secondly, after analysing the data the researcher found there are 89 taboo words found in 5 songs of Rich Brian (Back at it, Crisis, dat \$tick, Seventeen and Who that be). Thirdly, obscenity is the most commonly kind of taboo word used in 5 songs of Rich Brian and profanity is the least kind of taboo word used by Brian. Lastly, the most widely used function of taboo word is showing contempt. This is due to the majority of the meaning of Rich Brian's song lyrics showed disrespect feeling toward the addresse and to insult the situation or environment. And the least used function of taboo words is mocking authority.

\section{SUGGESTIONS:}

\section{To English Student}

The students especially English Education Student is not allowed to use taboo words. This is due to the fact that the use of taboo words is not Indonesian's culture and it breaks the norms of polite behaviour and ethic applied in Indonesia. Then, it is suggested to English students for avoiding this kind of song because it is not recommended song to sing.

2. To English Teacher

It is suggested to English teacher who want to use song as the media of learning to not to take this kind of song, because it is not suitable to be the media of learning due to the number of taboo words existed in these song.

3. To other researcher

It is suggested to the next researcher who wanted to take the same subject as the researcher to conduct further research about taboo words in different context, for instance study about the use of taboo words in novel, and study about the relationship between the use of taboo words and gender issue. 


\section{REFERENCES}

12. (2019, April 3). Slang for police. Retrieved From: urbandictionary.com

Affini, Laily Nur. Analisis Kata Tabu dan Klasifikasinya di Lirik Lagu Eminem pada Album The Marshal Mathers LP. Article, Indonesia: Universitas PGRI Semarang (Upgris)

Allan, K. and Burridge, K. 2006. Forbidden Words: Taboo and the Censoring of Language. New York: Cambridge University Press.

Anggita, Fika Nur. (2015). A Sociolinguistic Analysis Of Taboo Words In Bad Teacher Movie. Thesis, Yogyakarta State University, Indonesia.

Battistella, Edwin.L. 2005. Bad Language: Are Some Words Better than Others? New York: Oxford University Press.

Crabtree and Miller. 1999. Doing your Qualitative Research. New York: SAGE Publications

Dahlan, Ahmad. (2018, December 16). Definisi Sampling Serta Jenis Metode dan Teknik Sampling. Eureka Pendidikan. Retrieved From: https://www.eurekapendidikan.com/2015/09/defenisi-sampling-danteknik-sampling.html

Fromkin, Victoria dan Robert Rodman. 1993. An Introduction to Language. USA:Holt, Rinehart and Winston, Inc

Freud, S. 1999. Totem and Taboo. Trans. James Strachey. London: Routledge.

Gao, Chunming. (2006). A Sociolinguistic Study of English Taboo Language. Journal of Theory and Practice in Language Studies, Vol. 3, No. 12, pp.2310-2314. Finland: Academy Publisher. 
Hudson, R. A. (2000). Sociolinguistics (Second edition). Beijing: Foreign Language Teaching and Research Press and Cambridge University Press.

Holmes. (2001). An Introduction to Sociolinguistics. New Zealand: Longman

Hornby, A.S. (2015) Oxford Advanced Learner's Dictionary of Current English (Ninth Edition). Oxford University Press, UK.

Manopo, Jesika Regina ( 2014) Kata-Kata Tabu Dalam Film Bad Teacher Karya Lee Eisenberg Dan Gene Stupnitsky (Suatu Analisis Sosiolinguistik). Journal Article, Indonesia: Universitas Sam Ratulangi

Martinet, 1987. Ilmu Bahasa: Pengantar. Yogyakarta: Digital Library of State University of Malang. Kanisius

Meilasari, Priska., Nababan,M.R., Djatmika (2016). Analisi Terjemahan Ungkapan Eufemisme dan Desfemisme Pad Teks Berita Online BBC. Journal of Linguistics, 1 (2), 339-340.

Nugraha, Raindra Yudha and Nugroho, Raden Arief ( 2017) Subtitling Strategies Of Taboo Words Used In Fans Sub And Pro Sub In "The Wolf Of Wall Street" Movie. Journal Article, Dian Nuswantoro University, Indonesia.

Panjaitan, Lidik (2013). A Sociolinguistic Analysis Of Taboo Words In Kreayshawn's Song Lyrics. Unpublish Thesis. Bengkulu: Universitas Bengkulu

Putra, Wahyu Adi. (2016). Taboo Words In The Jackass Movie. Thesis, State Islamic University Sunan Kalijaga Yogyakarta, Indonesia. 
Putri, Sri Rahayu. (2017). An Analysis Of Taboo Words In Fast And Furious Series 1 Movie. Unpublish Thesis. Bengkulu: Universitas Bengkulu

Rich Brian Biography. (2018, December 3rd). Wikipedia. Retrieved from https://en.m.wikipedia.org/wiki/Rich_Brian

Rich Brian's song lyrics. (2019, January 23rd). Genius. Retrieved from : https://genius.com/Rich-brian-song-lyrics

Romaine, S. (2000). Language in Society An Introduction to Sociolinguistics. New York: Oxford University Press.

Spears, Richard A. (1990). Forbidden American English: A Serious Compilation of Taboo American English. USA:Passports Book

Sugiyono (2008). Metode Penelitian Kulitatif dan R\&D. Bandung, Indonesia: Alfabeta

Suryani, Dian. (2015). An Anlysis of Taboo Words in M.I.A.M.I Sampler Album By Pitbull. Unpublish Thesis. Universitas Bengkulu, Bengkulu

Trudgill, Peter. 2000. Sociolinguistics: An Introduction to Language and Society London: Penguin Books

Undang-undang Republik Indonesia Nomor 14 Tahun 2005. (2018, November 1 ). Wikisource. Retrieved from https://id.wikisource.org/wiki/UndangUndang_Republik_Indonesia_Nomor_14_Tahun_2005

Wardhaugh, Ronald. (2000). An Introduction to Sociolinguistics (Third edition). Oxford: Blackwell Publishers Ltd. 
Wardhaugh, Ronald. (2006). An Introduction to Sociolinguistics (Sixth edition). Oxford: Blackwell Publishers Ltd.

Winda, Deviyanti (2017) Slang Dalam Lirik-Lirik Lagu Chris Brown. Journal Article, Indonesia: Universitas Sam Ratulangi.

\section{Writer Information}

\begin{tabular}{|l|l|}
\hline Name & Derli Elsa Putri \\
\hline Affiliation & $\begin{array}{l}\text { English Education Study Program, Department of } \\
\text { Languages and Arts, University of Bengkulu }\end{array}$ \\
\hline Email & derlielsa97@gmail.com \\
\hline Phone Number & $\mathbf{0 8 2 2 8 0 5 1 0 2 6 2}$ \\
\hline
\end{tabular}

